\title{
Tristis Amor: an unpublished verse love letter from Lady Elizabeth Dacre Howard to Sir Anthony Cooke
}

\author{
Elaine Treharne
}

Some time in the 1550s or 1560s, Lady Elizabeth Dacre Howard (wife of Baron Dacre of Gilsland until his death in 1566, and then briefly third wife of the fourth Duke of Norfolk until her death in 1567) wrote a highly personal Latin quatorzain addressed to Sir Anthony Cooke the Protestant educator, and father of the Cooke sisters. This love poem was placed in a 1561 edition of The Works of Chaucer, and, when the volume was rebound, the loose-leaf folio was pasted into the back of the codex. This essay traces the people involved in this story and provides an edition and translation of this previously unpublished work. The discovery of the poem and its aristocratic female author adds considerably to the debate on English women writers and their education in the Renaissance and makes a contribution to our apprehension of literate communities in this period. Moreover, Dacre's ownership of the Chaucer volume unequivocally demonstrates the appeal of Chaucer to an educated and well-connected Catholic woman.

\section{THE CONTEXT}

West Virginia University Library's Special Collections in Morgantown owns an extensive range of books collected by a WVU alumnus, Arthur S. Dayton, and bequeathed to the university after his death in 1948. Among these volumes are the four folios of Shakespeare's plays published in the seventeenth century, and many significant first editions of literary works from the early modern period to the Victorian era. One of the canonical stars in this collection is the 1561 folio edition of Chaucer's works containing additions by John Stow, and edited by William Thynne:

In the preparation of this paper, I have received feedback from a number of colleagues, to whom I am immensely grateful: Dr Orietta Da Rold; Professors Colin Burrow, Anne Coldiron, Patrick Conner, Thomas Keymer, Elizabeth Spiller and Greg Walker. Dr Sarah Knight assisted me in uncovering the correct Elizabeth Dacre and made useful suggestions in the transcribing of the poem; Dr Jane Marie Pinzino improved my initial translation of the poem; and Drs Phillip Lindley and John Blatchly kindly answered my queries about the tomb and brasses in Kenninghall Church. Many thanks to the anonymous readers for their useful suggestions. 
The woorkes of Geffrey Chau- | cer, newly printed, with divers ad- | dictions, whiche were neuer in printe before: with the siege and | destruccion of the worthy citee of Thebes, compiled | by John Lidgate, Monke of Berse, ${ }^{1}[$ sic $]$ | As in the table more plainly | dooeth appere.

Imprinted by John Kingston for John Wight, and sold in St Paul's Churchyard, the volume has a number of marks of ownership. The first owner's inscription is that of 'Elizabeth Dacres', entered onto the title page to the right of the title in a formal sixteenth-century italic hand; as will become clear, this presents firm evidence for a female Catholic owner of the Thynne-Stow edition on or near its publication. ${ }^{2}$ A subsequent owner's inscription is also on the title page as 'Peter Shee', dated '3rd Feb. 1812' (Fig. 1), and 'E. H. S.' also appears in pencil on the title page. It is likely that this owner had the volume rebound, since the marbled endpapers are commensurate with such a date. The names of the twentieth-century owners of the book appear in bookplates on the inside front cover. Prior to Dayton's acquisition and donation to WVU, the book was owned by the famous Shakespearean actors Edward Hugh Southern (the 'E.H.S.' of the title page; he lived from 1859-1933) and Julia Marlowe Southern (1865-1950); their names appear in a scroll with the motto 'Alta Peto' on Southern's heraldic shield. ${ }^{3}$ Dayton's own name appears in a bookplate denoting his donation to WVU.

While the Chaucer edition itself is of great interest, and perhaps the more so because of its ownership by Edward Hugh Southern, the inside back cover provides evidence of another text, once concealed within the printed leaves. It is a Latin blank-verse quatorzain, 'Ad Anthoninus Cokinij', written in dark ink on a single sheet of paper measuring $150 \mathrm{~mm}$ by $205 \mathrm{~mm}$, which was presumably tucked into the Chaucer, and is now positioned permanently inside the back cover, framed by the pastedown, and labelled at the bottom with a pasted-in signature reading 'Elizabeth Dacres' (Fig. 2). Named both as the addressee of the epistolary verse, and named again within the poem, is 'Anthony Coke' (Antoninus Cokinus), the 'sweet love' of 'Dacre', who, given the sixteenth-century historical evidence, can only be Sir Anthony Cooke (or Coke), erstwhile tutor to Edward VI, and well-known literary figure. The writer

\footnotetext{
${ }^{1}$ John Lydgate, monk of (what should read) Bury St Edmunds.

2 This counters the emphasis on Protestantism usually attributed to the various sixteenth-century readers of the Thynne editions of The Workes of Geffey Chaucer. See Deanne Williams, 'Medievalism in English Renaissance Literature', in Kent Cartwright (ed.), A Companion to Tudor Literature (Oxford: Blackwell, 2010), 213-27, at 217-18.

${ }^{3}$ Comprised of three eagles displayed sable on a diagonal band. I owe a significant debt of gratitude to Professor Patrick Conner at West Virginia University, who sent me an extended description of the volume and its signs of ownership, upon which the details here are based, with his permission. Professor Conner hopes to publish more extensive notes on this volume in the near future. The Thynne is a fourth collected edition, second issue: title page in second state; Prologues in 5 leaves instead of 9 and not illus. Thynne's edition with additional poems appended by Stow. Cf. Pollard, Short Title 5076 and British Library, General Catalogue, v.36, col. 452. Thank you very much to Harold Forbes, Special Collections' Librarian at West Virginia University, for his assistance and support during this project and for introducing me to this edition of Chaucer on my visit to West Virginia University in February 2010.
} 


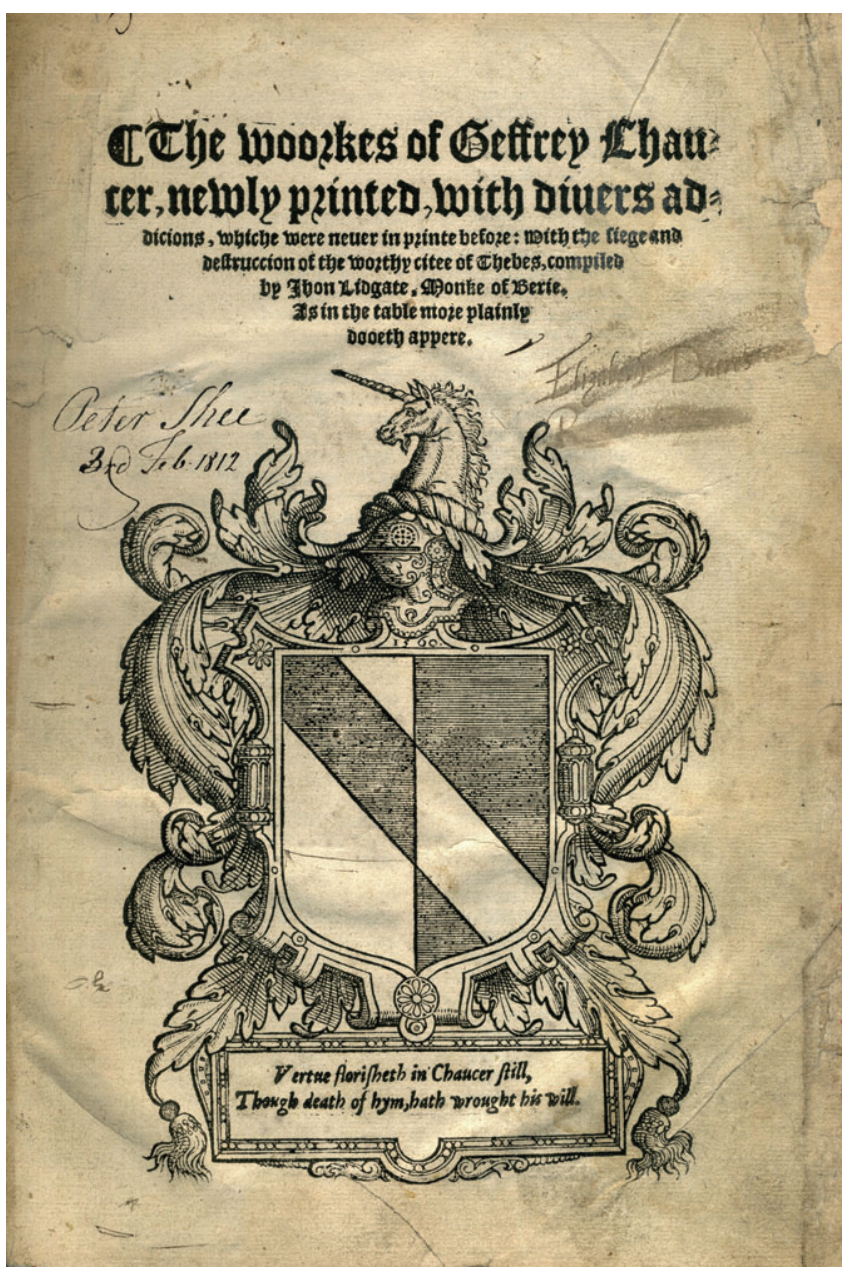

Fig. 1 Title page, 1561 William Thynne edition of The Woorkes of Geffrey Chaucer, signed by Elizabeth Dacre (used by kind permission of the Rare Books Collection, West Virginia University Libraries)

of the verse is Elizabeth Dacre, wife first of the Fourth Baron Gilsland, and thereafter, from January to September 1567, Elizabeth Howard, Duchess of Norfolk. The poem and excerpted attribution, then, might well have been repositioned at the time of the book's rebinding in the nineteenth century. The signature of Elizabeth Dacre beneath the poem is written in a different script, but the signature 'Elizabeth Dacres' on the title page, as far as one can deduce, is identical to the hand that writes the poem, and it seems entirely likely that the poem and at least one of the signatures belong to Dacre herself, and one should surmise from this that the verse is a holograph. Thus, one can note the obvious similarities in letter-form between the word dacre in line 14 


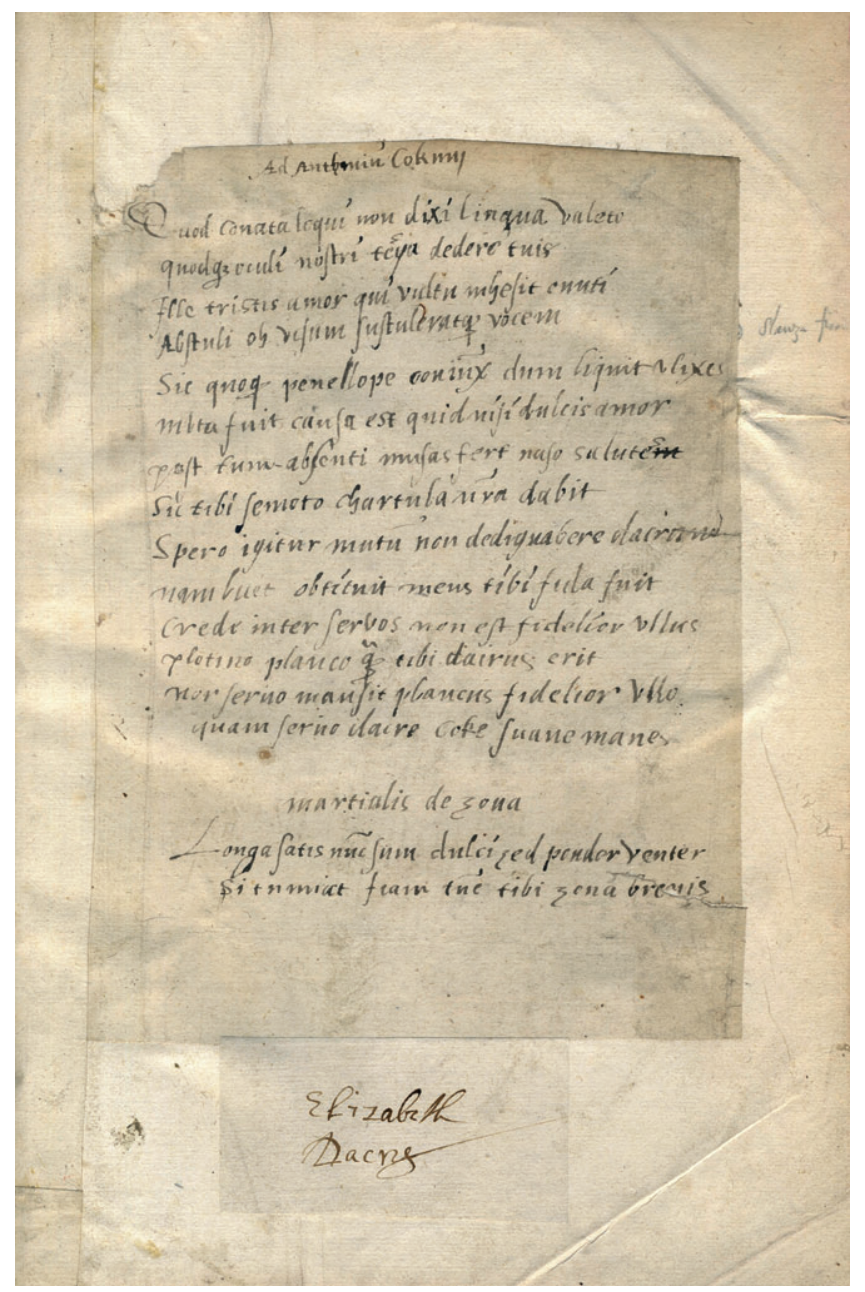

Fig. 2 'Ad Anthoninus Cokinii', repositioned as pastedown inside back cover of the Thynne Chaucer (used by kind permission of the Rare Books Collection, West Virginia University Libraries)

and the -acre- in the title-page signature, together with the forms of $l, b, z$, and $h$ in the poem and in Elizabeth in that same signature.

The poem as we have it seems to be a fair copy, since it is meticulously written out with attention to neatness, calligraphic consistency, and freedom from error; indeed, there is only one emendation: at line 7 where salutem has been corrected to salutes. This correction may have been made a little later, perhaps on re-reading, since the ink looks a tad darker than the original (as with the two-line text of the epigram at the bottom of the page, which Dacre may have gone to look up before returning to write, or might have added as 
an afterthought), but whatever the case, it has disrupted the rhyme scheme, such as it is. The script of the poem is a hybrid italic-secretary hand (as is the script of the title-page signature): it is relatively formal, with few cursive features (st ligatures appear at line 2 nostri, line 4 Abstuli and sustuleratque, and line 7 post) and only a handful of common abbreviations; namely, qz for que (lines 2, 4, 5), te'r'ga with superscript $r$ (line 2), and the macron denoting omission of the nasal (coniunx, line 5; nunc, line 16). Typical features of italic script are the indistinguishable $u$ and $n$ (for example, plancus, line 13$) ;{ }^{4}$ the curved ascenders of $b$ and $l$; the unflourished $d, f, g, k$ and $x$. More typical of secretary hand are the small $t$; the $h$ with its right limb sweeping under the line; the $z$ with its flicked descender (lines 13 and 15 zona); and the initial $p$ with its otiose onstroke (line 7 , post and line 12 plotino). The scribe is careful to dot the $i$ 's and maintain word-spacing, though capitalization is not absolutely consistent.

'To Anthony Cooke' is fourteen lines long, and completed by an additional two-line epigram of Martial. The scribe is careful to observe layout and capitalization, but it is actually difficult to tell whether or not this should be one long fourteen-line stanza with the epigram appended, or two quatrains and a sestet, or indeed, some other arrangement. Since verse layout by this point in the sixteenth century (somewhere in the 1550 s or early 1560 s) commonly incorporated white space to denote stanzaic separation, and since the Martial epigram is deliberately set apart by two lines-worth of space while the preceding fourteen lines are not arranged with notable space between them, I am interpreting this poem as a quatorzain in my conservative edition of the work below.

\section{THE PEOPLE}

While the 1561 edition of Chaucer is of intrinsic interest to early printed book specialists, and to Chaucer scholars for those whose focus is women's literacy in the early modern period, it is most interesting that Elizabeth Dacre was almost certainly the first to own this collection of Chaucer's work, purchased, one can surmise, quite soon after the volume's publication. She was born Elizabeth Leybourne (Leyburne, Leybourn) to Helen Preston ${ }^{5}$ and Sir James Leybourne of Cunswick, Earl of Westmorland, in 1536. She married Lord Thomas Dacre, Fourth Baron Gilsland, in 1555, and they lived in Naworth

\footnotetext{
${ }^{4}$ A feature of a sixteenth-century lady's hand, according to Jean F. Preston and Laetitia Yeandle, English Handwriting 1400-1650, MRTS (Binghamton, SUNY, 1992), Plate 19, an 'Autograph letter from Lady Grace Cavendish to Jane Kniveton, October 10, ca. 1585'.

${ }^{5}$ Helen Preston (d. 1571) married Sir James Leyburne first, and then Sir Thomas Stanley, 2nd Lord Monteagle: Charles Mosley, editor, Burke's Peerage, Baronetage Eं Knightage, 107th edition, 3 vols. (Wilmington DE, Burke's Peerage (Genealogical Books) Ltd, 2003), Volume 1, 1103. Thanks to Sarah Knight for alerting me to the sources for the correct Elizabeth Dacre.
} 
Castle, at Gilsland, and at other estates in the north-west. ${ }^{6}$ She bore him five children before his death in 1566: Francis, who died as an infant (though it is difficult to find evidence for this child's existence); George, the heir, who died in 1569, aged seven; Anne (1557-1630), who became Countess of Arundel as wife of St Philip Howard; ${ }^{7}$ Mary (1563-1578), briefly married to Thomas Howard, Earl of Suffolk; and Elizabeth (1564-1639), known in her later life as 'Bess of the Broad Apron', who married Lord William Howard, the renowned antiquarian, and the inheritor through Elizabeth of the Dacre lands in the north of England. ${ }^{8}$

On 29 January 1567, a few months after her first husband's death, Elizabeth Dacre was married to the ostensibly Protestant Thomas Howard, the fourth Duke of Norfolk, thus consolidating two aristocratic families with very extensive landholdings in the north-west and east of England, particularly. ${ }^{9}$ Plans for the marriage had been made known to Elizabeth I prior to the ceremony. State Papers by the Spanish ambassador for January 1557 reveal that:

The Duke has told the Queen that he has arranged to marry the widow of Lord Dacre of the North, which was, as I wrote your Majesty, being secretly negotiated. After he had spoken to the Queen about it, the Duke at once came to inform me, repeating that he and all his house desired to serve your Majesty, and I verily believe that his will is good, he being a good and honest gentleman. When I said to the Queen that she had not told me anything about the Duke's marriage she said she had known nothing about it herself until that moment. ${ }^{10}$

The Spanish ambassador also reported on the wedding of Elizabeth Dacre and Thomas Howard at the London house of Elizabeth's mother (now Lady Monteagle). The account is restrained, but enthusiastic about Elizabeth's devotion to Catholicism and optimistic that she might prevail in persuading the duke to convert to Catholicism:

\footnotetext{
${ }^{6}$ See, inter alia, S. G. Ellis, Tudor Frontiers and Noble Power: the Making of the British State (Oxford: Oxford University Press, 1995); Steven G. Ellis, 'Dacre, William, third Baron Dacre of Gilsland and seventh Baron Greystoke (1500-1563)', Oxford Dictionary of National Biography, Oxford University Press, 2004; online edn., Jan 2008, http://www.oxforddnb.com.proxy.lib.fsu.edu/view/article/46514, (accessed 27 Nov 2010).

${ }^{7}$ Nancy Pollard Brown, 'Howard [Dacre], Anne, Countess of Arundel (1557-1630)', ODNB, http:// www.oxforddnb.com.proxy.lib.fsu.edu/view/article/46907, (accessed 10 April 2011).

${ }^{8}$ Richard Ovenden and Stuart Handley, 'Howard, Lord William (1563-1640)', ODNB, http:// www.oxforddnb.com.proxy.lib.fsu.edu/view/article/13947, (accessed 10 April 2011).

${ }^{9}$ Note from the preceding paragraph that the three Dacre girls were married to their step-brothers, the three Howard boys, in an arrangement made by the fourth Duke of Norfolk after his wife's death. Even before they married, he had been agitating for the guardianship of the Dacre children. See Michael A. R. Graves, 'Howard, Thomas, fourth Duke of Norfolk (1538-1572)', ODNB, http://www.oxforddnb.com.proxy.lib.fsu.edu/view/ article/13941, (accessed 10 April 2011).

10 'Simancas: January 1567', Calendar of State Papers, Spain (Simancas), Volume 1: 1558-1567 (1892), 607-15. URL: http://www.british-history.ac.uk/report.aspx?compid=86791\&strquery=Dacre, (accessed: 30 November 2010).
} 
The duke of Norfolk was married on the 29th ultimo, without any rejoicing or demonstration. He was married at the house of his wife's mother, who with her daughter are good and virtuous Catholics, and if they quite win over the Duke to their religion, it will be a great gain to the country, as he has a large following and is a good and upright gentleman. ${ }^{11}$

It might be supposed that there was little by way of celebration for a number of reasons: Elizabeth's first husband had died only a short period before; and she was, it seems possible, already pregnant with Thomas Howard's child. Either way, Elizabeth and Thomas Howard had little time to enjoy their married life, because Elizabeth died in childbirth at the Howards' main residence, Kenninghall Palace in Norfolk, a mere seven months after their London wedding on the 4th September 1567. She was interred on 18 September 1567 in St Mary's Church, Kenninghall, but has no known tomb or grave there. ${ }^{12}$ At that time, although Richard Nuham was vicar of Kenninghall, William Hughes, the Duke of Norfolk's chaplain and later Bishop of St Asaph, sought permission from Lord Burghley to preach the sermon at the funeral of Elizabeth Dacre. ${ }^{13}$

In her own right - as an individual and not simply a daughter, wife and mother - the paragraphs above are almost all that one can garner about Dacre from the surviving evidence that has been known to date. The Thynne Chaucer at West Virginia University provides new evidence for Elizabeth's ownership of a key literary work, and thus suggests something about Catholic reading interests in the early years of Elizabeth I's reign, since Dacre was certainly a committed Roman Catholic. Whether or not Dacre actually read Chaucer's work in detail is a moot point; she owned it and had the ability to read his varied oeuvre, as did a significant number of women readers throughout the early modern period. Wiggins estimates, from her research sample, that perhaps 20 per cent of readers of Chaucer in the Renaissance period were women, including gentry women in the north, such as Dorothy and Anne

\footnotetext{
11 Ibid. The same record reports later that the duke and his wife retired home on 4 February, 1567, home being Kenninghall, or less likely, Framlingham.

${ }^{12}$ It seems a little odd that Elizabeth Dacre has no memorial, given that the duke outlived her by nearly five years (though some of those imprisoned in the Tower for plotting to marry Mary, Queen of Scots). His first and second wives - Mary FitzAlan and Margaret Audley - are commemorated by an elaborate tomb in St Michael the Archangel's, Framlingham. There is a large gap between their sculptures on the tomb, which is rumoured to be for his third wife, or for him. At St Mary's in Kenninghall, there is an aristocratic tomb just inside the chancel, but all of its brass furniture has been removed. Dr John Blatchly, in private correspondence, tells me that it is a man's tomb, and it is said to be that of Margaret Audley's father, George and his wife. See Francis Blomefield's An Essay Towards a Topographical History of the County of Norfolk 1 (London, W. Bulmer, 1805), 224. Blomefield also reports that Thomas Howard's sister, Jane, Countess of Westmorland, who died in 1593, was buried at St Mary's, but has no known memorial. Thanks to my mother, Iola Treharne, for sharing her considerable knowledge of Renaissance England during a research tour around the Kenninghall area.

${ }^{13}$ Calendar of State Papers, Domestic Series, of the Reigns of Edward VI, Mary, Elizabeth, 1547-1580: Elizabeth I (Elz Vol. XLIV, 5), 299 (SP 12/44 f.13), Sept. 121567.
} 
Vernon of Haslington, Cheshire. ${ }^{14}$ In Dacre's case, this reading material, together with her proficiency in Latin, suggest that she enjoyed the kind of education prescribed for an Elizabethan court lady ${ }^{15}$ (but at least a decade prior to Elizabeth's reign). Moreover, the poem that she has left to posterity is another indicator of her reading, her learning, and her relationships: the poem addressed to the educator, literary scholar, gentleman, minor politician and erstwhile tutor of Edward VI, Sir Anthony Cooke of Gidea Hall, Essex $(1505 / 6-76){ }^{16}$

This poem should be seen in the intellectual context outlined by Jane Stevenson in her work on female Latin poets. In the sixteenth century, evidence for the education of women was provided by John Coke's Debate betweene the Heraldes of Englande and France, published in 1550: 'Also we haue dyvers gentylwomen in Englande, which be not onely well estudied in holy Scrypture, but also in Greke and Latyn tonges, as maystres More, maystres Anne Coke [later the wife of Sir Nicholas Bacon], Maystres Clement [Margaret Gigs, Thomas More's foster daughter], and others . . ${ }^{17}$ It is perhaps not a surprising coincidence that Anne Cooke, daughter of Sir Anthony Cooke is mentioned in her brother's list of notable female scholars since Anthony Cooke was well known in his own day as an educator, particularly of women, though he himself was self-taught. The link between Elizabeth Dacre and Sir Anthony Cooke, confirmed by the poem she wrote to him, raises the possibility that she was tutored by him, or was known to him through a network of educators and their tutees. He was renowned for his own erudition and diplomacy, and is described by the seventeenth-century writer, David Lloyd as being 'somebody in every art, and eminent in all the whole circle of Arts lodging in his soul. His Latine, fluent and proper; ... his Rhetorick and Poetry, copious and genu-

\footnotetext{
14 Alison Wiggins, 'What did Renaissance Readers Write in their Printed Copies of Chaucer?', The Library 9 (2008), 3-36, esp. 25-9.

${ }^{15}$ Jane Stevenson, Women Latin Poets: Language, Gender and Authority from Antiquity to the Eighteenth Century (Oxford: Oxford University Press, 2005), 260-69 discusses the ladies of court and their learning. Among the authors to be read by court women were Ovid, Virgin, Dante, Petrarch, Chaucer and Surrey. Elizabeth Dacre clearly knows Chaucer, Ovid, and Martial, together with Valerius Maximus.

${ }^{16} \mathrm{~J}$. W. Binns, Intellectual Culture in Elizabethan and Jacobean England: The Latin Writings of the Age, ARCA 24 (Leeds, Francis Cairns, 1990), 196-7 on Cooke's literary circle, which included Sir John Cheke, among others; see 313 for his tutorship of Edward VI. Cooke was married to Anne Fitzwilliam, who died in 1553. On Cooke, see especially M. K. McIntosh, 'Sir Anthony Cooke: Tudor Humanist, Educator, and Religious Reformer', Proceedings of the American Philosophical Society, 119 (1975), 233-50; and Donn L. Calkins, 'Cooke, Sir Anthony (1505/6-1576)', ODNB, http://www.oxforddnb.com.proxy.lib.fsu.edu/view/article/6155, (accessed 10 April 2011). On his daughters, see Lynne Magnusson, 'Bacon [Cooke], Anne, Lady Bacon (c.1528-1610)', ODNB, http://www.oxforddnb.com.proxy.lib.fsu.edu/view/article/987, (accessed 10 April 2011); and Caroline M. K. Bowden, 'Cecil [Cooke], Mildred, Lady Burghley (1526-1589)', ODNB, http://www.oxforddnb. com.proxy.lib.fsu.edu/view/article/46675, (accessed 10 April 2011).

17 Cited in Jane Stevenson, Women Latin Poets: Language, Gender and Authority from Antiquity to the Eighteenth Century (Oxford: Oxford University Press, 2005), 255.
} 
ine. . . ${ }^{18}$ There, he is cast as 'breeding statesmen', rather than being one himself, though he was a member of the Privy Chamber during the reign of Edward VI. ${ }^{19}$ Lloyd further describes Cooke as having recreations 'that were moderate, lawful, sober, becoming, useful and seasonable'. There is no hint of impropriety or scandal, though little is known of his private life. He certainly taught his daughters well, since each of them had a very notable role to play in the nation's political, cultural and intellectual life,,$^{20}$ and Calkins points out that Cooke made sure that his daughters read the 'works of contemporary protestant thinkers'. ${ }^{21}$ Mildred Cooke married William Cecil, Lord Burghley and was revered as a scholar and patron of the arts in her own right; ${ }^{22}$ Anne Cooke, who published Italian and Latin translations, married Sir Nicholas Bacon and was mother to Sir Francis Bacon; Katherine Cooke, a linguist of great merit, married Sir Henry Killigrew; Elizabeth Cooke, the Latin translator, married John, Lord Russell; and Margaret Cooke became lady-in-waiting to Queen Mary. During the reign of Mary, Anthony Cooke himself, who seemed to be very much a Protestant, undertook voluntary exile. This makes his relationship with Elizabeth Dacre, a confirmed and lifelong Catholic, more intriguing. It is curious that she, as such a committed Catholic, would have had any kind of personal relationship with Cooke, an enthusiastic Protestant, at least on the surface. ${ }^{23}$ In 1553, he took himself off to Strasbourg, where he knew many reformers and from where he wrote occasionally to his son-in-law, William Cecil, Lord Burghley. ${ }^{24}$ Upon his return to England in 1558, Cooke's status and influence were greatly enhanced by his association with Burghley; extant letters written by acquaintances to Cooke seek his intercession with Burghley, and he is documented as having a good relationship with his

\footnotetext{
18 David Lloyd, 'Observations on the Life of Sir Anthony Cooke', in his State-worthies, or, The States-men and Favourites of England since the reformation, (London: Thomas Milbourne, 1670), 374-77. I owe this reference to McIntosh, 'Sir Anthony Cooke', 233-4.

19 Calendar of State Papers, Domestic Series, of the Reign of Edward VI, 1547-1553, Edward VI, 666, 243, SP 10/14 f. 99, June 19, 1552.

${ }^{20}$ Mary Ellen Lamb, 'The Cooke Sisters: Attitudes Towards Learned Women in the Renaissance', in Margaret Patterson Hannay (ed.), Silent But for the Word: Tudor Women as Patrons, Translators, and Writers of Religious Works (Ohio: Kent State University Press, 1985), 107-25.

${ }^{21}$ Calkins, 'Cooke, Sir Anthony (1505/6-1576)', ODNB.

${ }^{22}$ Jane Stevenson, 'Mildred Cecil, Lady Burleigh: Poet, Patron, Politician', in Victoria Burke and Jonathan Gibson (eds.), Early Modern Women's Manuscript Writing: Selected Papers of the Trinity/Trent Colloquium, The Early Modern Englishwoman (Aldershot, Ashgate, 2004), 51-73.

${ }^{23}$ It has to be said that in the case of Thomas Howard, fourth Duke of Norfolk and apparent Protestant, his choice of a devout Catholic wife like Elizabeth seems curious, but can be explained by their mutual desire to enhance their wealth and landholdings; in the case of Cooke, a well-known Protestant intellectual, it is much less clear how his (perhaps very dangerous) relationship with Elizabeth might have developed. McIntosh, 'Sir Anthony Cooke', presents a balanced view of Cooke, illustrating his religious conservatism and political expediency, and questioning the depth of his recently acquired Protestant views up to 1553 or thereabouts when he went into exile (238-43).

${ }^{24}$ In a letter to Cecil in 1556, for example, Cooke expresses his relief at hearing of the birth of Mildred Cecil's daughter ('although a son might have been more welcome'!): Calendar of the Manuscripts of the Most Hon. the Marquis of Salisbury, Preserved at Hatfield House, Hertfordshire, Vol. 1: 1306-1571, Reign of Philip and Mary I, 511, 138, Jan. 10, 1556.
} 
son-in-law. ${ }^{25}$ No doubt his association with the court gave him plenty of opportunity to meet other courtiers, including those he might have known in earlier years during Edward's reign. Among these may have been aristocrats, such as Thomas Dacre, fourth Baron Gilsland and his wife (or wife-to-be), Elizabeth.

There is a little more to be learned about Elizabeth from extant sources. She was, according to her daughter Anne's biographer, 'Daughter of Sir James Labourn a Knight much esteem'd and honour'd in Lancashire. For her Beauty, Person, Wit, and Discretion, she was qualify'd to wear a Crown. ${ }^{26}$ From the Life of the Countesse of Arundel, too, it seems Elizabeth had at least her daughters, if not her son, brought up by her mother, the Lady Monteagle ('a grave, discreet, and vertuouse Matron... [and]... religious good Catholick'), ${ }^{27}$ and remained devoutly Catholic herself. Her husband, however, would not allow her access to a Catholic priest as she laying dying in labour:

the Duchesse ... desir'd to have been reconciled by a Priest, who for that end was conducted into the garden, yet could not have access unto her, either by reason of the Duke's vigilance to hinder it, or at least of his continual presence in the chamber at that time. ${ }^{28}$

Despite this final indignity, which rather calls into question the duke's devotion to his new wife, or at best indicates his unwillingness to compromise his apparent Protestantism, Elizabeth was rather tougher than she might seem thus far. Something of her determined nature and her political acuity may be derived from the reaction of her brother-in-law to her. Following Elizabeth's death in 1567, Norfolk became guardian of the Dacre children and had the case of his guardianship discussed by a special Commission. ${ }^{29}$ Upon the Dacre heir's death, when young George was crushed in an accident with a wooden horse, Norfolk applied for, and obtained inheritance of all the Dacre lands for the three remaining daughters of Elizabeth and Thomas Dacre. Leonard Dacre, brother of the fourth Baron Gilsland, ${ }^{30}$ was outraged by the loss of his own claim to the land, and seems particularly to have been full of hatred for his sister-in-law, Elizabeth. In a letter of advice sent to Leonard Dacre by one Richard Atkinson in 1570, the issue of the inheritance of the Dacre lands highlights this antipathy:

\footnotetext{
${ }^{25}$ For example, Dr Christopher Mont wrote to Cooke asking him to intercede with Cecil to speed up business relating to the Elector Palatine in Strasbourg: Calendar of State Papers Foreign, Elizabeth 1558-1559, Vol. 8, 1556-1558, Elizabeth I, 776, 142, SP 70/86 f. 108, Oct. 28, 1566.

${ }^{26}$ Duke of Norfolk (ed.), The Lives of Philip Howard, Earl of Arundel, and of Anne Dacres, his Wife edited from the Original Manuscripts (London: Hurst \& Blackett, 1857), 167.

27 Norfolk, The Lives of Philip Howard, Earl of Arundel, and of Anne Dacres, 168.

28 Norfolk, The Lives of Philip Howard, Earl of Arundel, and of Anne Dacres, 171.

${ }^{29}$ On this case, see Neville Williams, Thomas Howard Fourth Duke of Norfolk (New York: Dutton, 1964), 116-19.

${ }^{30}$ Henry Summerson, 'Dacre, Leonard (d. 1573)', ODNB, http://www.oxforddnb.com.proxy.lib.fsu.edu/ view/article/6994, (accessed 10 April 2011).
} 
Your unnatural brother [Thomas 4th Lord Dacre] won the hearts of the country by his house-keeping, and got praise of the nobility. Suggestions of a mode of raising fines on your tenants, to discharge the payments to which you were bound for your livery, and the great arrears the land is charged with, by means of the cursed woman, lady to your unfaithful brother [Elizabeth, widow of Thomas Lord Dacre, re-married to Thomas Duke of Norfolk]. You will not offend God by taking double rents; it is but a year's fine to begin with, and any other lord would charge higher rents.... The greedy tyrant [the Duke of Norfolk] might have granted you a living of as much value somewhere, but it would only be for a little space; he will be a covetous traitor all his days, he has entered on all your living, and now will on all your father's substance, and like a greedy dog, would let you and your brothers starve to death. This are a company of hell-hounds, as Lowther, Carleton, the Whelpdales, the Bosts of Deston(?), related to your enemy, the now dead Duchess. Whelpdale said he would be bold to say that since the death of Lord George, your nephew there never would be a Lord Dacre again ... This woman, your enemy dead, was the Duke's fall, for her wealth and words made him forget God, and shoot at all ... You first spoke to him of the ward's keeping, and then enemies prevented you, and he got it by marrying her. You and the Council were deceived, but I was not, for I said when I heard you had so agreed, that you would repent it; you should beware of covetousness in men of such height as he was then, for you thought you could not match her but by him, and thus he got her and ward and all. He shortened her days, and was the death of Lord George; then he had a clean way, having the ward's coheirs in governance. ${ }^{31}$

Clearly, Elizabeth and Leonard were old and deeply embittered enemies, and though this polemic surely exaggerates her role, it does strongly suggest that she was able to wield considerable influence over her first husband, and had equally strong influence (through 'her wealth and words') over the Duke of Norfolk. The descriptions of her here also emphasize her political vision, intelligence and ambition. Quite what Atkinson means by his accusation against the Duke of Norfolk that 'he shortened her days and was the death of Lord George' is unclear and smacks somewhat of a conspiracy theory against the duke, but it still strikes me, perhaps naively, as curious that Elizabeth has no monumental memorial and has all but disappeared from record.

\section{THE POEM}

The poem unequivocally demonstrates Elizabeth Dacre's classical learning, metrical and poetic training, and awareness of contemporary poetic form. If

\footnotetext{
31 Calendar of State Papers, Domestic Series, of the Reign of Elizabeth, Addenda 1566-1579, Elizabeth I, Vol. XVIII, 11. III, 255 (SP 15/18 f.37), 1570 (Richard Atkinson to Leonard Dacre). For a brief account of the conflict between the Dacres and the Howards, see Ovenden and Handley, 'Howard, Lord William (1563-1640)', ODNB. In Anglorum Speculum, or The Worthies of England, published in 1684 by 'G. S', priests in Cumberland at the time of Elizabeth Dacre are given as (the earlier) Roger Whelpdale and Roger Layburn, of the same noble family as Elizabeth, sole daughter and heir of Sir Francis Leyburn, who was married to the last Baron Gilsland and Greystoke (EEBO, Wing [2nd ed.] / S22B.
} 
we are to take the work at face value, the poem becomes a declaration of love with erotic overtones indicating, perhaps, an illicit love affair between an older gentleman, Anthony Cooke, and a younger female aristocrat, Elizabeth Dacre. There is nothing beyond the poem, however, to substantiate a love affair, and it may be entirely a work of fiction in the tradition of many other love poems, and particularly sonnets, of the period. It may have been written, as Jane Stevenson demonstrates in relation to other poetic composition of the period, to prove one's 'ability to produce a well-turned poem in one or other of the learned languages [which] was one of the ways in which sixteenth-century politicians sorted out the players from the pawns: to exchange verse, and to respond intelligently to the reception of verse, was in itself a tool of diplomatic life. ${ }^{32}$ Yet, if it is a fiction, a poetic artifice, the use of the poet's real name, together with the opening dedication to Anthony Cooke, and the explicit and tender final line seem rather peculiar.

\section{Ad Anthonin us Cokinii ${ }^{33}$}

Quod conata loqui ${ }^{34}$ non dixi lingua valeto quodque oculi nostri terga dedere tuis Ille tristis amor qui vultu inhesit eunti Abstuli ob visum sustuleratque vocem Sic quoque Penellope coniu $n \mathrm{x}$ dum liquit Vlixes muta fuit, causa est quid uisi dulcis amor post tum absenti musas fert Naso salutes ${ }^{35}$ Sic tibi semoto chartula nostra dabit Spero igitur mutu $m$ non dedignabere Dacrium nam luet obticuit ${ }^{36}$ mens tibi fida fuit Crede inter servos non est fidelior vllus Plotino Planco qua tibi Dacrus erit noster seruo mansit Plancus fidelior vllo quam seruo Dacre Coke suaue manes

\footnotetext{
32 Stevenson, Women Latin Poets. 265.

${ }^{33}$ Transcribed from the manuscript (Fig. 2). Abbreviations have been expanded and are shown by italics. Capitalization and punctuation follow the manuscript, except for personal names, which I have capitalized (Penellope, Ulixes, Naso, Dacrium, Plotino Planco, Plancus, Dacre).

34 conata loqui, Ovid, Heroides 4, Phaedra to Hippolytus, based ultimately on Euripides' non-extant Hippolytus Crowned. Phaedra cannot speak directly with Hippolytus because of modesty, and must declare her love in a letter, which she hopes he will read, because even enemies, she says, read each other's letters. She reveals: 'Ter tecum conata loqui, ter inutilis haesit/ Lingua, ter in primo destitit ore sonus.' ['Three times I tried to speak with you, three times my Tongue fail'd; three times the words abandoned me at my tongue's end.'] These opening two lines also syntactically echo Ovid's Heroides 4 with their alternating phrases.

35 Corrected in the text from salutem.

${ }^{36}$ Corrected from ms. obtituit, as helpfully suggested to me by Colin Burrow.
} 
Martialis De zona ${ }^{37}$

Longa satis nunc sum dulci sed pondere venter si tumeat fiam tunc tibi zona brevis

[To Anthony Cooke

The goodbye I tried to speak but could not utter with my tongue by my eyes I delivered back to yours.

That sad love that haunts the countenance in parting contained the voice that I concealed from display, just as Penelope, when her husband Ulysses was present, was speechless - the reason is that sweet love of a gaze. Then afterwards Ovid sends greeting muses to the absent, just as to you, distant, I have sent my small note.

I hope then that silent Dacre will not be scorned by you for the mind has suffered and held fast in faithfulness to you. Believe that among servants there is not any more faithful: as Plancus Plotinus thus will Dacre be to you. I remain your servant Plancus, more faithful than any; to this servant Dacre, you remain sweet Coke.

Martial, Of the girdle

Long enough am I now; but if your shape should swell under its grateful burden, then shall I become to you a narrow girdle.]

How are we to regard this poem? There are elements of the sonnet form - the octave and sestet seem implicit in the poem with a turn from past to present at line 9, a turn from silence and concealment of emotion to open declaration of hope for the future. But this is neither decasyllabic nor pentametrical, nor are there more than a few hints of rhyme. The English sonnet, as opposed to the Petrarchan form permitted greater freedom in its composition, but not enough freedom to dispense with metre and rhyme. There are examples of end-rhyme here (lines 8, 10 and 12, for example; lines 1 and 3 might constitute a half-rhyme), and there is obvious echo at the end of lines 11 and 13, but this does not seem regular enough to form a distinctive generic pattern. It may be preferable to think of it as a quatorzain, a fourteen-line poem not adhering to the rules of a sonnet; and though its metre is also difficult to interpret (particularly within a Latin tradition), it does have a regular attempt at fourteen syllables per line, and thus might be emulating a syllabic prosody, rather

\footnotetext{
${ }^{37}$ D. R. Shackleton Bailey, ed. and trans., Martial Epigrams, The Loeb Classical Library, 3 vols. (Cambridge MA: Harvard University Press, 1993), cli, A Female Girdle.
} 
than a metrical one. ${ }^{38}$ Within this fourteen-line verse is immense concentration of emotion forming the expression of a particular thought, with a dense summation of all the argument that precedes it being encapsulated within the final unrhymed couplet at lines 13-14. Where many poems, including sonnets, close with an internal epigram, Dacre's speaker closes with an added two-line scurrilous Martial epigram, which may be humorous or teasing, if this were a poem to a tutor, but which really seems more scurrilous and suggestive than that, stating rather baldly how sexually attracted she is to Cooke, how desirous of his physical presence.

The poem might properly be thought of in the tradition of the epistolary Heroides, particularly since it quotes directly from that work of Ovid, a work that was fundamental to a cultured education in the sixteenth century. ${ }^{39}$ This popular literary genre was widely emulated in Renaissance Europe, ${ }^{40}$ and involved 'emotionally charged tales of lovelorn women', ${ }^{41}$ but unlike these emulative epistles, Dacre's poem possibly involves real lovers - herself and Cooke, and unlike these other examples Dacre writes in Latin. ${ }^{42}$ For Renaissance women, Ovid's Heroides may have offered 'a model of "feminine" writing with which to revise Petrarchism for use by women poets', ${ }^{43}$ giving women poets a voice within a familiar form. Raphael Lyne has recently discussed the complexity of interpreting poet and poetic voice, where the female voice in intertextual Heroidean fiction becomes a source of control. ${ }^{44}$ Here, though, Dacre is neither ventriloquized, nor suppressing her identity; instead, she literally takes control through her double self-inscription in the poem's closing lines. In her verse, Dacre shows herself to be more than competent at Latin composition, choosing the erudite language of the scholar over the available vernaculars to demonstrate her learnedness, and perhaps to disguise her writings from those less learned than her. In addition to rejecting the vernacular, in showing her knowledge of Ovid, of Valerius Maximus, and of

\footnotetext{
38 Thanks to Dr Rebecca Stephenson for her assistance with the metre, which we both view as irregular, though Dr Stephenson sees an attempt at hexametricality, and wonders if the poem might not be following another language's rhythms (such as English's, of course, as I suggest is the case with the fourteen-syllable line). Thanks also to Dr Emily Thornbury for her advice on the irregular metre.

${ }^{39}$ See Jane Stevenson, 'Women, Writing and Scribal Publication in the Sixteenth Century', English Manuscript Studies 1100-1700 9 (2000), 1-32, at 14.

${ }^{40}$ This is cited, of course, by Lucentio and Bianca in Act 3, Scene 1, 25-36 of The Taming of the Shrew, as Colin Burrow has kindly reminded me.

${ }^{41}$ Yvonne LeBlanc, 'Queen Anne in the Lonely, Tear-Soaked Bed of Penelope: Rewriting the Heroides in Sixteenth-Century France', Disputatio 1 (1996), 71-87, at 72. It is interesting that the love epistles of the writer, La Vigne, included heroes or heroines whose names began with the same letter (LeBlanc, 73), as do Penelope and Plancus Plotinus in 'To Anthony Cooke'.

${ }^{42}$ Sidney's sonnets, written later in the sixteenth century, also feature real historical figures. The poems emerge as somewhere between fantasy and fact, depicting idealized love that need never have occurred.

43 Patricia Phillippy, "Altera Dido”: The Model of Ovid's Heroides in the Poems of Gaspara Stampa and Veronica Franco', Italica 69 (1992), 1-18. It is the case that the Heroides also provided a model for male writers to ventriloquize female characters.

${ }^{44}$ Raphael Lyne, 'Intertextuality and the Female Voice after the Heroides', Renaissance Studies 22, 3 (2008), 307-23. I owe this reference to this article's anonymous reader.
} 
Martial, Dacre also deliberately rejects the models of religious writing for women; ${ }^{45}$ and she rejects contemporary dictates on the literature that is admitted for women's reading. For example, in his Preface to The Instruction of a Christian Woman, Vives pours moral scorn on Ovid, as he sets out what is suitable for female education ("As for a woman she hath no charge to see to, but her honesty \& chastitie.'):

In my mynde no man was euer banyshed more ryghtfully/ than was Ouide/ at lest wise if he was banisshed for writyng the crafte of loue. For others write wanton and noughty balades/ but this worshipful artificer/ must make rules in goddis name and preceptes of his vnthriftines/ a scholemaister of baudry/ and a common corrupter of uertue. ${ }^{46}$

Dacre's choice to write a secular love poem in Latin, replete with erotic overtones and containing multiple references to those whom Vives would consider 'masters of baudry' surely illustrates the work of a strong-minded, educated, independent woman, who is deliberately rejecting (albeit in private) the contemporary stereotype of the modest woman. The irony of using a 'common corrupter of virtue' like Ovid while writing a poem that is explicitly amatory and sexual - whether fictional or otherwise - would not have been lost on Dacre or her addressee. ${ }^{47}$ Moreover, in her private writing, made public here for the first time, Elizabeth Dacre demonstrates a degree of mastery of rhetoric reinforcing the sense of a highly educated and appropriately formal discourse. Perhaps the choice of somewhat unregulated rhyme and the medium of Latin was also a deliberate attempt to distance herself from the usual vernacular rhyme of the sixteenth-century female poet in an effort to impress her learned recipient all the more. ${ }^{48}$

In choosing to compare herself to Penelope, who is typically understood as the archetype of chaste and loyal wifely patience, ${ }^{49}$ Dacre very much casts her speaker in the role of the lonely Ovidian heroine, who beseeches her husband to send back not a note, but himself. Here, Dacre's persona records that she has written to Cooke in his absence a chartula, a small note, and the reciprocity she desires is his presence. The comparison with Penelope, wife of Ulysses, is both presumptuous and tragic. Penelope waited twenty years for the return of her husband from the Trojan expedition - an implicit indication of Elizabeth's patience, loyalty, and absolute desire for Cooke. But she, of course, was

${ }^{45}$ Lamb, 'The Cooke Sisters'.

${ }^{46}$ Juan Luis Vives, trans. Richard Hyrde, A very fruitfull and pleasant booke, called the Instruction of a Christian Woman (London, Robert Waldegraue, 1585), Preface, 4-5. This book was originally dedicated to Catherine of Aragon.

47 On Ovid, rhetoric, the body and voice, with reference to the Metamorphoses, see Lynn Enterline, The Rhetoric of the Body from Ovid to Shakespeare (Cambridge: Cambridge University Press, 2000). I owe this reference to Colin Burrow.

48 There are a number of examples in Stevenson, 'Women, Writing and Scribal Publication'.

${ }^{49}$ LeBlanc, 'Queen Anne in the Lonely, Tear-Soaked Bed of Penelope', 82. 
not Cooke's wife. In fact, she may have been betrothed to Thomas Dacre at the time that she claimed to be longing for Cooke's return. In any case, her comparison of Cooke and Ulysses makes of him a man bereft of comfort while away from his wife - in this instance, Elizabeth, his (possible? actual? fictional?) lover. The Heroidean influence is evident in the phrase conata loqui too, where the silence of Phaedra is broken only by her sending of a passionate letter to her absent lover, Hippolytus - the letter being the means by which secrets are sent over land and sea. ${ }^{50}$

The silence of the lover is a theme that dominates this poem, and is arguably one of the strongest indicators of an illicit affair, since silence and discretion would be essential in such a situation. If this affair occurred, it might have taken place, perhaps at court, around 1553, at which time Cooke left for the Continent for five years, his own wife Anne having died in that same year. At the time, Elizabeth Dacre would have been perhaps seventeen years old, two years or so before she married Lord Dacre in about 1555 . Her mother, Lady Monteagle, had a house in London, where Elizabeth presumably stayed. The commission, official Visitors of the London diocese, was headed by Cook, so he was certainly in London during the years 1547-53 he was a Member of Parliament; and, in 1552, he was charged to examine heresies and ensure the adoption of the Book of Common Prayer. ${ }^{51}$ By 1553, however, he was in the Tower of London, suspected of involvement with the Lady Jane Grey plot. ${ }^{52}$ It was after this that he left England for the Continent, the period of exile to which Elizabeth Dacre's letter might, conceivably, refer. However, since the leaf on which the poem is written is in excellent condition, unfolded, as found by the nineteenth-century binder or owner within the pages of the Chaucer, and since the Chaucer volume cannot be dated prior to 1561, it may be that the relationship with Coke, and her recording of it through this poem, dates to after Mary's reign, when Coke returned from the Continent.

Whether this poem records an amorous relationship, or something more akin to a display of poetic erudition (which just does not seem to do justice to the personal and tender lament here), its private nature is evinced in the poem's hidden history, and in the touching scene it depicts. The pregnant silence that Elizabeth breaks in her writing she talks of as contained within a gaze, 'the sweet love of a gaze' for her 'sweet Coke'. This gaze, used to intimate intimacy that is clandestine, is seen in an account of a meeting of former lovers at a dinner-party, published by George Gascoigne in his Hundred Sundrie Flowers in 1573:

Nowe, although there were wanted no delicate viands, to cont $<$ ent $>$ them, yit their chief repast was by entreglancing of lookes. For GG being stoong with hot

\footnotetext{
${ }^{50}$ Ovid, Heroides, 4, Phaedra to Hippolytus.

51 McIntosh, 'Sir Anthony Cooke', 241.

52 McIntosh, 'Sir Anthony Cooke', 242.
} 
affection, could not otherwise relieve his passion but by gazing. And the Dame of a curteous inclination deigned (now and then) to require the same with glancing at him. Hir old louer occupied his eyes with watching: and hir brother perceuying all this could not absteyne from winking, whereby he might put his Sister in remembrance least she shold too much forget herself..$^{53}$

This amusing scene with all manner of communication taking place paralinguistically through varied expressions, lingering looks, winks and glances reminds us of the silent agency of women in this period. In 'To Anthony Cooke', it is clear that Dacre's persona is not just a willing participant in the relationship, but through this poem and its epigram, an instigator of its continuation, despite her muteness through shyness or etiquette in person. And despite the cliché of being able to read another person through the expression in their eyes, here the reciprocity of feeling is captured in the second line - quodque oculi nostri terga dedere tuis - with her sad, silent gaze and its communicative clarity returning his own sorrowful longing.

The sense of the slow passage of time through melancholy is enhanced by the poet's promise of continued faithfulness to Cooke, and the repetition of mansit (line 13) and manes (line 14). The final four lines introduced with Crede (You believe) and completed by manes (you remain), emphasize the focus on Cooke and the requirement for Dacre that he maintain his belief in her. This desire is poignantly underlined by the opening of the final six lines, which marks the turn of this poem: Spero (I hope). The urgency she seems to feel is heightened by the double allusion to Plotinus Plancus, a Roman moneyer who had servants of immense fidelity, but who was more faithful to them even than they were to him. This reference, known in the Renaissance from the Latin work of Valerius Maximus' Memorable Deeds and Sayings, ${ }^{54}$ testifies to the endurance and willingness of servants from classical exempla, who will suffer any torment to remain loyal to their lords. Plotinus Plancus was proscribed by the triumvirate in $43 \mathrm{BC}$ and hid in Salernum, but his perfume revealed him to those searching for him, and he voluntarily surrendered, and was executed, in order to save his slaves who were being tortured to death rather than reveal his whereabouts. ${ }^{55}$ Dacre will have known this text from the Latin original, since I can find no evidence for an English translation before the 1590s, and must have been aware of Cooke's knowledge of the text too; without such shared knowledge, the reference would be of little significance. The implication is

\footnotetext{
${ }^{53}$ This passage is quoted in a longer form in Stevenson 'Women, Writing and Scribal Publication', 5, and discussed at 4-6.

${ }^{54}$ Valerius Maximus' Memorable Deeds and Sayings: One Thousand Tales from Ancient Rome, trans. Henry John Walker (Indianapolis: Hackett Publishing, 2004), Ch. viii.5, 'De fide servorum erga dominos'. It is found in the Renaissance in the English Palace of Pleasure conteyning store of goodly histories, tragicall matters, and other morall argument, very requisite for delighte and profit. Chosen and selected out of diuers good and commendable authors, by William Painter, clerke of the ordinance and armarie (London, 1567).

${ }^{55}$ See Georges Dumezil, Camillus: A Study of Indo-European Religion as Roman History, ed. Udo Strutynski (Berkeley: University of California Press, 1980), 162, who comments that in 47 BC, Plautius Plancus was a moneyer, whose coins feature Medusa, among other designs.
} 
that she will remain faithful to him - more than any other could - until her death.

Little could anyone know that Dacre would die at the age of about thirty, leaving a noble dynasty of great significance to this day who remain in situ in many of the houses in which Dacre herself lived. She left little trace of herself, and has been useful for the footnotes in others' lives - until the discovery of this poem. From it, it is clear that she was an educated woman, who was well read in the Latin classics and in earlier English literature, like Chaucer's works. Like Cooke, she knew 'Rhetorick and Poetry', and now she can be studied, too, as part of the wider circle of women readers and writers who have been ably discussed by Jane Stevenson, Victoria E. Burke and others. ${ }^{56}$ Elizabeth Dacre was literate in the truly learned sense of that word; she was also ambitious and intimately involved in the highest echelons of aristocratic life in England at the height of the Tudor period. Here, though, in her words to Anthony Cooke, as real or fictional lover, we gain a unique insight into the poetic projection of the personal, silent, and private world of an educated and determined Renaissance woman, who wanted what was hers, even if he was not.

Florida State University

${ }^{56}$ See references above, and also Perdita: http://www.warwick.ac.uk/english/perdita/html/. 


\section{Abstract}

ELAINe TREHARne, Tristis Amor: an unpublished verse love letter from Lady Elizabeth Dacre Howard to Sir Anthony Cooke

This article brings to light a previously unknown Latin epistolary love poem, written by Lady Elizabeth Dacre-Howard, third wife of the fourth Duke of Norfolk, and addressed to Sir Anthony Cooke, tutor to Edward VI, and father of the Cooke sisters. Its physical context contained within Elizabeth Dacre's 1561 Thynne edition of Chaucer demonstrates a Catholic woman's ownership of Chaucer's works, but also indicates the private nature of the verse. The poem references Ovid's Heroides, Valerius Maximus, and contains an explicit Martial epigram, highlighting Dacre's classical education; it is thus no surprise that she writes in Latin, even though contemporary women seem rarely to do so. The rhetorical skill and tenderness of tone suggest a woman lamenting an absent lover, here, unusually, named as Anthony Cooke. Whether this poem represents a real love affair or an exercise in composition, it heralds a new author in the history of English women's literature - a female author who knew her own mind and was herself the mother of remarkable Catholic noblewomen and thence a major aristocratic dynasty.

Keywords: Anthony Cooke, Elizabeth Dacre, newly discovered female-authored Latin love poem 